\title{
Letters
}

\section{Running as a Team}

With his discussion of party elders, parliamentary continuity, and collegial decision-making under Eisenhower, Rockman, in the last of the four Summer (1987) PS co'er essays, dances closest to our idea of the president running with a proposed cabinet. Even Arkes' lament of the loss of presidential standing and Edwards' recognition of the laziness of focussing on the individual executive and the need to "devote more attention to the context in which the chief executive seeks to achieve his goals" provide good starting points to discuss the importance of the cabinet.

Fascinating though Milkis' tracing of the imperial presidency may be, we would go a step beyond his observation that ironically it will have to be an imperial president himself who chooses to restrain his own power.

We would go beyond that and say that the candidate who shows the foresight and surety of ego to name men and women whose expertise in various fields have drawn him or her to "embody" the party's platform by naming these "elders" (to use Rockman's term) in advance... . such a candidate, working from the unorthodox logic of this deeply democratic idea, is showing strong leadership worthy of respect. And the American people will respond intuitively to the logic of governance by a circle of elder-experts.

Think of the photo possibilities alone!! And think of the chance for national brainstorming on the substantive issues in each of the cabinet areas.

The alternative is to continue with the same dreary, mindless personality contests in which less and less people $(20 \%$ of the electorate currently) feel the need to participate. Futurist Timothy Leary in a recent Los Angeles lecture put it this way:

Anyone running for president as the job exists today should automatically be dis- qualified. The language screws us up. There's all this warrior imagery. They 'fight' and 'campaign' and 'win.' Imagine the nation as an airplane with over 200 million passengers. Currently, the would-be pilots stagger around the passenger area for two years mugging and beating each other up. Then, the most brutal, bloody survivor of these 'campaigns' staggers to the control cabin to fly the plane. But what does he know about navigation? I want a president who sees himself or herself as a crew captain or coach; not a 'hot-dog' or a 'star.' Then, the focus is on the team or the crew. $\mathrm{He}$ could have jesse Jackson as left flank; Sam Nunn as defense, Raiph Nader to watch over the trees and air quality.

Prof. Robert Salisbury of Washington University at St. Louis in his piece in the June 1, 1987 Christion Science Monitor and $M$. Scott Peck in the final chapters of the best-selling The Different Drum; Community Making and Peace echo our sentiments too. I hope your readership will begin to direct their discussion toward the value of "running the team instead of the prom queen." And I hope to hear from anyone interested, pro or con.

Glenn Hopkins

L.A. Spokesperson, New Age Network

\section{Administrative History}

I'm seeking to purchase the four volumes by Leonard $D$. White on administrative history: The Federalists, The Jeffersonians. The Jacksonians and The Republican Era. The volumes were published by The MacMillan Company.

Also, I am interested in other works on the topic of administrative history in the United States and elsewhere. Please contact me at (617) 573-83/5 or at Suffolk University, School of Management, Beacon Hill, Boston, MA 02108.

Fran Burke Professor, Suffolk University 